\title{
MELIHAT GEJALA SOSIAL YANG ADA DI MASYARAKAT PADA ERA COVID-19
}

\author{
Nama : ARIF ABIYYU MUSBAR \\ Email:arifabiyyu2018@gmail.com \\ No BP: 2110003600152 \\ Kelas : $1 \mathrm{H3}$ \\ Prodi : Ilmu Hukum \\ Perguruan Tinggi : UNIVERSITAS EKASAKTI
}

\section{A. PENDAHULUAN}

sejak jumlah kasus Covid-19 meningkat di Indonesia, berbagai permasalahan sosial dan ekonomi muncul di tengah masyarakat. Tak dapat dipungkiri jika Covid-19 telah hampir melumpuhkan kondisi sosial ekonomi masyarakat Indonesia.

Akibat kasus Covid-19 ini, pemerintah Indonesia mulai melakukan berbagai kebijakan seperti mengeluarkan himbauan social distancing, mengeluarkan himbauan untuk Work From Home bagi pegawai, memberlakukan pembatasan wilayah, membangun RS khusus untuk penanganan Covid-19, dan lain-lain. Dengan adanya kebijakan pemerintah ini serta situasi yang semakin genting, tentunya memberikan dampak bagi masyarakat, baik masyarakat menengah ke bawah hingga kalangan elit. Berbagai masalah sosial ekonomi muncul dan dampaknya langsung terasa oleh masyarakat.

Meskipun Organisasi Kesehatan Dunia (WHO) telah resmi mengubah istilah social distancing menjadi physical distancing, banyak orang masih menggunakan istilah social distancing. Pengubahan istilah ini dimaksudkan agar interaksi antar masyarakat tetap berlangsung walaupun berjauhan fisik. Tentu hal ini lebih baik, mengingat dalam konsep social distancing telah membatasi interaksi sosial masyarakat. Dalam penerapan physical distancing masyarakat diminta agar tetap terhubung menjalin interaksi sosial dengan cara yang lain. Cara-cara yang banyak digunakan tentunya penggunaan cara-cara daring atau online. Walaupun kita di era informasi dan digital ini sudah cukup terbiasa dengan komunikasi secara daring ini, tetap saja, sebagai makhluk soial, tetap ada tuntutan untuk bertemu dan berinteraksi secara langsung dalam jarak yang cukup dekat. Terjadinya pembatasan berupa physical distancing ini tentunya memberikan dampak berupa permasalahan sosial tersendiri.

Permasalahan sosial sendiri merupakan suatu ketidaksesuaian antara unsur-unsur kebudayaan atau masyarakat yang membahayakan kehidupan kelompok sosial atau menghambat terpenuhinya keinginan-keinginan pokok warga kelompok sosial tersebut sehingga menyebabkan kepincangan ikatan sosial (Soekanto, 2013, dalam Alifa, 2020). Masalah sosial timbul dari kekurangan-kekurangan dalam diri manusia atau kelompok sosial yang bersumber pada faktor- 
faktor ekonomis, biologis, biopsikologis, dan kebudayaan. Semakin hari permasalahan sosial ekonomi yang ditimbulkan akibat Covid-19 semakin terlihat nyata bagi masyarakat. Beberapa masalah sosial ekonomi yang terjadi akibat Covid-19 diantaranya : kelangkaan barang, disorganisasi dan disfungsi sosial, tindakan kriminal, melemahnya sektor pariwisata, peningkatan angka kemiskinan dan pengangguran.

Selama terjadi pandemi Covid-19, pemerintah menghadapi masalah ekonomi, kesehatan maupun masalah sosial di Indonesia. Banyak artikel yang telah menyorot masalah ekonomi dan kesehatan masyarakat di masa pandemi Covid-19 ini. Oleh karenanya, artikel ini akan membahas masalah sosial akibat pandemi yang berkepanjangan.Pertumbuhan ekonomi yang menurun akibat terjadinya pandemi, mengakibatkan jumlah pengangguran, kemiskinan, serta PHK karyawan meningkat. Kondisi ini selanjutnya menimbulkan masalah sosial di kalangan masyarakat pada umumnya.Dalam menghadapi masalah yang ada, pemerintah telah mengambil berbagai tindakan penanganan masalah bidang ekonomi dan kesehatan.

Situasi sosial saat pandemi tidak pernah terbayangkan sebelumnya. Dampak wabah Covid19 telah memasuki kehidupan termasuk secara sosial. Interaksi sosial berubah drastis sehingga banyak kegiatan yang dilakukan secara virtual dan menimbulkan kebiasaan baru. Hal ini membuktikan apabila virus Covid-19 telah mengubah cara hidup masyarakat saat ini.

Tak hanya mengubah cara hidup, keterbatasan aktivitas juga menimbulkan masalah ekonomi dan sosial. Dampak penurunan ekonomi ini lalu berkembang menjadi masalah sosial. Masalah sosial tersebut antara lain:

- Meningkatnya kekerasan dalam rumah tangga.

- Masalah kriminalitas yang merebak.

- Masyarakat juga mengalami disfungsi sosial serta disorganisasi karena pembatasan aktivitas di luar rumah

Masalah sosial ini sulit untuk dihindari, sehingga berbagai upaya pencegahan perlu dilakukan oleh pemerintah. Penanganannya pun harus cepat dilakukan agar masalah sosial ini tidak meluas di kalangan masyarakat.

Gejala sosial adalah suatu fenomena yang ditandai dengan timbulnya permasalahan sosial yang mempengaruhi dan dipengaruhi oleh tingkah laku setiap individu di dalam lingkungan kehidupannya. Dengan kata lain, setiap gejala ini menjadi dampak sekaligus penyebab dari gejala sosial lainnya.

Gejala sosial adalah hal-hal yang menyebabkan terjadinya masalah sosial. Gejala sosial seringkali disamakan dengan masalah sosial, penting untuk dimengerti bahwa hal ini tidak tepat. Namun, kedua konsep memang saling berkaitan erat. Untuk memudahkan kita dalam 
membedakan gejala sosial dengan masalah sosial, berikut adalah sebuah contoh yang dapat gunakan untuk memahami masing-masing konsep. Ketimpangan ekonomi merupakan sebuah gejala sosial, gejala sosial tersebut mengakibatkan terjadinya sebuah masalah sosial, yaitu kriminalitas yang dilakukan oleh masyarakat miskin. Istilah "gejala" pada konsep ini berasal dari pendekatan positivisme, yaitu cabang ilmu sosial yang diturunkan dari tradisi ilmu alam.

Pada dasarnya semua manusia menginginkan kehidupan yang baik, yaitu terpenuhinya kebutuhan hidup, baik kebutuhan jasmani, kebutuhan rohani, maupun kebutuhan sosial. Manusia berpacu untuk dapat memenuhi berbagai kebutuhan hidupnya demi mempertahankan kehidupan diri sendiri, maupun keluarganya.

Berdasarkan uraian di atas, penulis tertarik untuk membuat makalah dengan judul "Melihat Gejala Sosial Yang Ada Di Masyarakat Pada Era Covid-19" 


\section{B. PEMBAHASAN}

Gejala sosial adalah peristiwa-peristiwa yang terjadi di antara dan oleh manusia, baik secara individu maupun kelompok. Kegiatan masyarakat melahirkan gejala sosial.

Gejala sosial dapat terjadi di mana saja, baik di perkotaan maupun pedesaan. Namun, di wilayah perkotaan, profesi lebih beragam daripada pedesaan. Masyarakat di perkotaan pun cenderung heterogen, berbeda dengan di pedesaan yang lebih homogen. Selain itu statifikasi dan diferensiasi sosial di pedesaan lebih sederhana daripada perkotaan.

Gejala-gejala sosial yang ada di masyarakat dapat diartikan sebagai sebuah fenomena sosial. Munculnya fenomena sosial dimasyarakat berawal dari adanya perubahan sosial. Perubahan sosial itu tidak dapat kkita hindari, namun kita masih dapat mengantisipasinya. Perubahan sosial adda yang bersifat positif dan negatif, sehingga kita harus hati-hati dalam menghadapi perubahan yang terjadi. Fenomena sosial yang ada dalam kehidupan sehari-hari dapat dapat menimbulkan masalah sosial. Adapun beberapa contoh fenomena sosial seperti munculnya kesenjangan sosial, demam musik luar (boyband/girlband), pencemaran lingkungan, dan lain sebagainya. Gejala sosial juga diartikan sebagai suatu pristiwa yang sering terjadi pada lapisan masyarakat, baik masyarakat tradisional maupun masyarakat modern.

Macam-macam gejala sosial antara lain:

1. Gejala sosial religious, misalnya perayaan panen padi

2. Gejala sosial ekonomi, misalnya gejala menurunnya pertumbuhan ekonomi dan meningkatkan pengangguran

3. Gejala sosial politik, misalnya terjadinya praktik politik uang untuk memenangkan pemilu

4. Gejala sosial hukum, misalnya ketidakdisiplin pengendara sepeda motor di jalan raya

Pemerintah telah berupaya mempercepat stimulan di sektor perekonomian dengan membuat kebijakan dan penanganan yang tepat demi menjaga ekonomi dan sosial yang stabil. Hal ini penting dilakukan karena akan memengaruhi keselamatan seluruh lapisan masyarakat.

Untuk mengatasi masalah sosial di Indonesia masa pandemi, pemerintah telah sebelumnya melakukan berbagai langkah. Beberapa di antaranya yang bisa dicatat adalah:

- Bantuan dan Jaringan Pengaman Sosial. Perlindungan sosial dengan cara menyalurkan bantuan dan membuat jaringan pengaman sosial. Ini dilakukan khususnya terhadap penduduk yang miskin serta rentan terhadap dampak pandemi. 
- Bantuan sosial. Bantuan sosial yang dilakukan pada tahun 2020 lalu meliputi Program Keluarga Harapan (PKH) untuk 10 juta keluarga, Kartu Sembako bagi 20 juta penerima, Kartu Prakerja pada lebih dari 5 juta orang, pembebasan tarif listrik 450 VA dan diskon tarif listrik $900 \mathrm{VA}$.

- Kebijakan baru terkait Bansos. Selain itu pemerintah pun melakukan tambahan kebijakan baru terkait Bansos atau bantuan sosial, yaitu bantuan khusus bahan pokok sembako bagi masyarakat DKI dan Jabodetabek.

- Bantuan Sosial Tunai. Masyarakat di luar Jabodetabek yang tidak mendapat Bansos PKH ataupun Bansos Sembako akan mendapatkan Bantuan Sosial Tunai.

- Dana Desa. Masyarakat desa mendapatkan Dana Desa khusus bansos di desa.

- Meningkatkan anggaran bansos. Selain bantuan sosial, pemerintah melalui presiden secara langsung menyatakan akan menelaah kembali anggaran yang ada guna menambah bantuan sosial.

- Program Padat Karya. Tidak hanya bantuan sosial, pemerintah juga memperluas lingkup kerja bagi lapisan bawah di masyarakat melalui program padat karya.

- Program Padat Karya Tunai. Penguatan penyelenggaraan Program Padat Karya Tunai di lingkup kementerian.

- Program Keselamatan Polri. Program Keselamatan dilaksanakan oleh Polri dengan menggabungkan antara pelatihan dan bantuan sosial kepada pengemudi taksi, sopir truk bus, dan kernet.

kepedulian masyarakat tetap dibutuhkan khususnya kalangan atas terhadap berbagai masalah sosial. Masyarakat diharapkan dapat bergotong royong menjaga pencapaian pembangunan di masa pandemi.

\section{Contoh gejala sosial}

a. Kemiskinan

a) Kemiskinan Dalam sosiologi, kemiskinan merupakan suatu gejala sosial yang sering kita jumpai dalam kehidupan sehari-hari. Gejala sosial ini terjadi diberbagai negara di dunia 
termasuk Indonesia. Kemiskinan dapat dibedakan menjadi 2 yaitu:

- Kemiskinan absolut, yaitu seseorang atau sekelompok orang tidak dapat memenuhi kebutuhan minimum hidupnya.

- Kemiskinan relatif, yaitu seseorang atau sekelompok orang dapat memenuhi kebutuhan minimum hidupnya, namun dirinya masih merasa miskin bila dibandingakan dengan orang lain atau kelompok lain.

Kemiskinan dapat dikarenakan tidak mampunya seseorang dalam memenuhi kebutuhankebutuhan primer. Namun dalam sosiologi, salah satu faktor penyebab munculnya masalah tersebut karena lembaga kemasyarakatan tidak berfungsi dengan baik, yaitu lembaga kemasyarakatan dibidang ekonomi. Permasalahan tersebut dapat menyebar kebidang lainnya, seperti pendidikan, sosial, dsb.

\section{b. Kejahatan}

Kejahatan di Indonesia mengalami peningkatan di masa pandemi COVID19 yang menimbulkan keresahan di masyarakat. Penyebabnya tidak lain karena banyaknya korban PHK dan pembebasan narapidana oleh pemerintah terkait penyebaran COVID-19. Persoalan kejahatan yang meningkat di masa pandemic COVID-19, salah satunya adalah tidak diketahuinya akar permasalahan dalam penanggulangan kejahatan tersebut. Penelitian ini menggunakan metode penelitian yuridis normatif, dengan pendekatan konseptual. Fokus pengkajian mengenai faktorfaktor yang mempengaruhi terjadinya kejahatan selama masa pandemi COVID19, serta penanggulangannya, yang dilakukan dengan menggunakan perspektif kriminologi dan viktimologi, serta melihat fungsi Polri. "Faktor faktor yang mempengaruhi terjadinya kejahatan di masa pandemi dalam perspektif kriminologi adalah fakor ekonomi, lingkungan sosial pelaku, tempat kejadian perkara yang memungkinkan, peniruan kejahatan di wilayah lain (termasuk peran media)".

Adapun dalam "perspektif viktimologi adalah faktor perilaku korban, kelemahan biologis dan psikologis korban, dan situasi". Penanggulangan kejahatan selama pandemi yang telah dilakukan di POLRI cukup komprehensif yakni "penanggulangan secara preemtif, preventif dan repersif". Namun, dalam pelaksanaan fungsi POLRI dalam penanggulangan Kejahatan masih terdapat beberapa hambatan sehingga diperlukan optimalisasi fungsi POLRI dengan menggunakan perspektif Kriminologi dan Viktimologi.

\section{c. Masalah remaja}

Masa remaja adalah masa pencarian jati diri sehingga banyak remaja yang meniru tingkah laku orang lain. Tindakan remaja bila tidak terkontrol dapat menjadi suatu masalah sosial yang dapat merugikan diri sendiri dan orang lain. Masalah remaja ini ditandai oleh adanya keinginan untuk melawan ataupun sikap apatis. Pada masa ini seharusnya mereka mengenal nilai dan norma- 
norma yang berlaku dimasyarakat. Dengan mempelajari norma di masyarakat, diharapkan mereka dapat berprilaku dan tidak melakukan perbuatan yang menyimpang. Prilaku menyimpang yang dilakukan oleh remaja dapat beragam, sebagai contoh membolos, mencontek, pelanggaran lalu lintas dan lain sebagainya.

d. Masalah kependudukan

Indonesia adalah negara dengan tingkat kepadatan penduduk yang padat. Penduduk merupakan sumber penting bagi pembangunan. Hal ini dikarenakan penduduk menjadi subjek dan obyek pembangunan. Dengan adanya pembangunan dapat meningkatkan kesejahteraan penduduk disuatu negara. kesejahteraan penduduk juga mengalami gangguan yang dipengaruhi oleh perubahan demografis yang sering sekali tidak dirasakan. Masalah kependudukan dapat berupa kepadatan penduduk, pemerataan penduduk yang tidak rata, ledakan penduduk dsb. Masalahmasalah diatas perlu adanya penanggulangan, karena dapat mempengaruhi tingkat kesejahteraan penduduk. Adapun beberapa cara untuk mengatasi permasalahan tersebut diantanya:

- Melalui program keluarga berencana (KB)

- Transimigrasi,dan

- Mengatur pertumbuhan jumlah penduduk

Setiap manusia dalam menjalani kehidupan sehari-hari di tengah masyarakat, akan menghadapi suatu kenyataan berupa kebutuhan yang harus dipenuhi, agar ia bisa bertahan dalam kehidupannya, selain kebutuhan ada juga keinginan seseorang yang juga menuntut agar bisa dipenuhi (Christianto, 2011). Terkait dengan adanya penyebaran wabah Corona Virus Disease 2019, selanjutnya disebut COVID-19 di Indonesia saat ini, ternyata ada peningkatan yang cukup drastis terhadap angka kriminalitas di Indonesia.

\section{Faktor Penyebab Gejala Sosial}

1. Faktor Kultural merupakan nilai-nilai yang tumbuh dan berkembang di lingkungan masyarakat/komunitas. Ada beberapa contoh gejala sosial berdasarkan factor kultural, antara lain kemiskinan, kerja bakti, perilaku menyimpang, dsb.

2. Faktor Struktural merupakan suatu keadaan yang mempengaruhi struktur, struktur yang dimaksud adalah sesuatu yang disusun oleh pola tertentu. Faktor struktural dapat dilihat dari pola-pola hubungan antar individu dan kelompok yang terjalin dilingkungan masyarakat. Contoh gejala sosial yang dipengaruhi oleh faktor struktural seperti penyuluhan sosial, interaksi dengan orang lain dsb. 


\section{Gejala Sosial Akibat Pengaruh Perubahan Sosial}

a. Globalisasi

Globalisasi adalah sistem ekonomi dan budaya global menyebabkan manusia di seluruh dunia menjadi satu kesatuan masyarakat tunggal. Adanya globalisasi memicu perubahan perilaku ataupun pola pikir.

b. Pola hidup kebarat-baratan (westernisasi)

Westernisasi adalah kecenderungan untuk menjadi sama dengan perilaku

masyarakat barat. Westernisasi mengakibatkan lunturnya rasa nasionalisme, menghilangkan jati diri bangsa, serta dapat mematikan kreativitas seseorang akibat peniruan budaya barat secara berlebihan.

c. Pola hidup modernisasi

Modernisasi adalah proses pergeseran sikap, karakter, dan perilaku masyarakat dalam menyesuaikan diri dengan perkembangan dunia terkini.

a. Sikap mengutamakan kepentingan dunia (hedonisme)

Orang yang menganut paham hedonisme didominasi oleh perilaku hidup bersenang- senang setiap waktu. Perilaku ini menyebabkan orang yang mengindahkan norma sosial menolak untuk bekerja dan tidak memiliki etos kerja.

b. Sikap hidup boros (konsumerisme)

Konsumerisme adalah kegiatan pembelian barang konsumsi yang berlebihan. Hal itu untuk gaya hidup modern semata.Terjadinya perubahan sosial-budaya dimasyarakat merupakan salah satu akibat dari gejala sosial. Dampak gejala sosial ada yang bersifat positif dan negatif. 


\section{PENUTUP}

Berdasarkan pembahasan yang telah dibuat pada makalah ini, maka dapat disimpulkan bahwa :

Gejala sosial adalah peristiwa-peristiwa yang terjadi di antara dan oleh manusia, baik secara individu maupun kelompok. Kegiatan masyarakat melahirkan gejala sosial.

Gejala sosial dapat terjadi di mana saja, baik di perkotaan maupun pedesaan. Namun, di wilayah perkotaan, profesi lebih beragam daripada pedesaan. Masyarakat di perkotaan pun cenderung heterogen, berbeda dengan di pedesaan yang lebih homogen. Selain itu statifikasi dan diferensiasi sosial di pedesaan lebih sederhana daripada perkotaan.

Sebab terjadinya gejala sosial adalah :

1. Faktor Kultural merupakan nilai-nilai yang tumbuh dan berkembang di lingkungan masyarakat/komunitas.

2. Faktor Struktural merupakan suatu keadaan yang mempengaruhi struktur, struktur yang dimaksud adalah sesuatu yang disusun oleh pola tertentu.

Pembahasan mengenai gejala sosial yang ada di masyarakat menjadi hal yang sangat penting, karena gejala sosial merupakan suatu fenomena yang ditandai dengan timbulnya permasalahan sosial yang mempengaruhi dan dipengaruhi oleh tingkah laku setiap individu di dalam lingkungan kehidupannya. 


\section{DAFTAR PUSTAKA}

Darmini Roza dan Laurensius Arliman S, Peran Pemerintah Daerah Di Dalam Melindungi Hak Anak Di Indonesia, Masalah-Masalah Hukum, Volume 47, Nomor 1, 2018. https://doi.org/10.14710/mmh.47.1.2018.10-21

Laurensius Arliman S, Peranan Metodologi Penelitian Hukum di Dalam Perkembangan Ilmu Hukum di Indonesia, Soumatera Law Review, Volume 1, Nomor 1, 201. http://doi.org/10.22216/soumlaw.vli1.3346.

Laurensius Arliman S, Peran Badan Permusyawaratan Desa di Dalam Pembangunan Desa dan Pengawasan Keuangan Desa, Padjadjaran Journal of Law, Volume 4, Nomor 3, 2017. https://doi.org/10.15408/jch.v4i2.3433.

Laurensius Arliman S, Penanaman Modal Asing Di Sumatera Barat Berdasarkan Undang- Undang Nomor 25 Tahun 2007 Tentang Penanaman Modal, Supremasi Hukum, Volume 1, Nomor 1, 2018. http://dx.doi.org/10.36441/hukum.v1i01.102.

Laurensius Arliman S, Memperkuat Kearifan Lokal Untuk Menangkal Intoleransi UmatBeragama Di Indonesia, Ensiklopedia of Journal, Volume 1, Nomor 1, 2018, https://doi.org/10.33559/eoj.v1i1.18.

Laurensius Arliman S, Perkawinan Antar Negara Di Indonesia Berdasarkan Hukum Perdata Internasional, Kertha Patrika, Volume 39, Nomor 3, 2017, https://doi.org/10.24843/KP.2017.v39.i03.p03.

Laurensius Arliman S, Partisipasi Masyarakat Di Dalam Pengelolaan Uang Desa Pasca UndangUndang Nomor 6 Tahun 2014 Tentang Desa, Jurnal Arena Hukum, Volume 12, Nomor 2, 2019, https://doi.org/10.21776/ub.arenahukum.2019.01202.5.

Laurensius Arliman S, Mewujudkan Penegakan Hukum Yang Baik Di Negara Hukum Indonesia, Dialogica Jurnalica, Volume 11, Nomor 1, 2019, https://doi.org/10.28932/di.v11i1.1831.

Laurensius Arliman S, Mediasi Melalui Pendekatan Mufakat Sebagai Lembaga Alternatif Penyelesaian Sengketa Untuk Mendukung Pembangunan Ekonomi Nasional, UIR Law Review, Volume 2, Nomor 2, 2018, https://doi.org/10.25299/uirlrev.2018.vol2(02).1587

Laurensius Arliman S, Peranan Filsafat Hukum Dalam Perlindungan Hak Anak Yang Berkelanjutan Sebagai Bagian Dari Hak Asasi Manusia, Doctrinal, Volume 1, Nomor 2,2016.

Laurensius Arliman S, Ni Putu Eka Dewi, Protection of Children and Women's Rights in Indonesia through International Regulation Ratification, Journal of Innovation, Creativity and Change Volume 15, Nomor 6, 2021.

Laurensius Arliman S, Gagalnya Perlindungan Anak Sebagai Salah Satu Bagian Dari Hak Asasi Manusia Oleh Orang Tua Ditinjau Dari Mazhab Utilitarianisme, Jurnal Yuridis, Volume 3, Nomor 2, 2016, http://dx.doi.org/10.35586/.v3i2.180.

Laurensius Arliman S, Tantangan Pendidikan Kewarganegaraan Pada Revolusi 4.0, Jurnal Ensiklopedia Sosial Review, Volume 2, Nomor 3, 2020.. 

